\title{
Dermatological alterations in women working on dairy farm: a case study
}

\section{Alterações dermatológicas em mulheres trabalhadoras de ordenha mecânica: um estudo de caso}

\author{
Marta Regina Cezar-Vaz ${ }^{\mathrm{I}}$ Clarice Alves Bonow ${ }^{\mathrm{II}}$ Anelise Miritz Borges ${ }^{\mathrm{II}}$ \\ Marlise Capa Verde de Almeida ${ }^{\mathrm{III}}$ Laurelize Pereira Rocha ${ }^{\mathrm{III}}$ Luana de Oliveira Severo ${ }^{\mathrm{III}}$
}

\section{ABSTRACT}

The present study aims to identify dermatological alterations due to the work carried out by women on dairy farms and presents an intervention process on dermatology health with women working in these locations. It is a quasi-experimental study, in an intervention form, in which each subject is independent. It was performed with 20 women working on a dairy farm in Rio Grande, Rio Grande do Sul, Brazil, between July and October 2011. Most (60\%) women identified dermatological changes due to the work. During the intervention, dermatological care action was focused on. The knowledge of these results offers valuable information for those who teach and advice people about dermatological care in rural working places, where such rates of occurrence are high.

Key words: cattle, human being, rural health, dermatology, occupational health nursing.

RESUMO

O presente estudo teve como objetivos identificar alterações dermatológicas decorrentes do trabalho de mulheres trabalhadoras de ordenha mecânica animal e apresentar um processo de intervenção sobre a saúde dermatológica com mulheres trabalhadoras de ordenha mecânica animal. Um estudo quase-experimental de intervenção, em que cada sujeito é controle dele mesmo, foi conduzido com 20 mulheres trabalhadoras de ordenha mecânica animal em Rio Grande, Rio Grande do Sul, Brasil, entre julho e outubro de 2011. A maioria (60\%) das mulheres identificaram alterações dermatológicas decorrentes do trabalho. Durante intervenção, foram enfocadas ações de cuidados dermatológicos. O conhecimento desses resultados são informações valiosas para aqueles que ensinam e aconselham sobre cuidados dermatológicos nos locais de trabalho rural, local em que as taxas de lesões são altas.

Palavras-chave: bovinos, ser humano, saúde da população rural, dermatologia, enfermagem do trabalho.

\section{INTRODUCTION}

The present study refers to the dermatological health of women working on dairy farms as well as to the development of a clinical intervention process for dermatological health directed towards these women. The International Labour Organization (LUCA et al., 2012) supports strategies that benefit health in the countryside, especially among women and children. Specifically, the women working on dairy farms play a significant role in the milk production, exposing themselves to health risks (FENTON et al., 2010).

In different countries, the health of women working on dairy farms is associated to safety when dealing with the animals (CARRUTH et al., 2002; FENTON et al., 2010; KALLOINIEMI et al., 2011). During the activity, the skin is an organ which requires attention because the frequent contact with the animals (KANERVA \& SUSTAIVAL, 1996) contributes to the development of dermatological clinical alterations. In Brazil, concern with dermatological health includes the risk perception due to the use of veterinarian pesticides by those working on dairy farms (SILVA et al., 2012).

Besides this, the Brazilian Rural Work Environment, Health and Security Management propose to implement health and security measures that aim the prevention of accidents and diseases

\footnotetext{
IEscola de Enfermagem, Universidade Federal do Rio Grande (FURG), 96200-400, Rio Grande, RS, Brasil. E-mail: cezarvaz@vetorial.net. Autor para correspondência.

${ }^{\mathrm{II}}$ Universidade Federal do Pampa (UNIPAMPA), Rio Grande, RS, Brasil.

"IUniversidade Federal do Rio Grande (FURG), Rio Grande, RS, Brasil.
} 
resulting from rural work. Such action should focus on minimizing the risks of rural work by adopting the measures of individual and collective protection, as educational campaigns (BRASIL, 2005). Thus, the present study has aimed to identify dermatological alterations due to the work carried out by women on dairy farms and presents an intervention process on dermatology health with women working in these locations.

\section{MATERIAL AND METHODS}

The method is quasi-experimental, in an intervention study form, in which each subject is its own control, and is composed of three phases. This study is part of a research project entitled "Health, Risks and Occupational Diseases: An Integrated Study in Different Work Environments" (CEZARVAZ, 2010). It was approved by the Research Ethics Committee of the Federal University of Rio Grande (FURG). The working women participated in the study after having read and signed the Free Consent Agreement. The study is linked to the Laboratory of Socio-environmental Process Studies and Collective Production of Health (LAMSA), a research group of the FURG School of Nursing and it is included in the Health Production in Different Work Environments Programs (HPDWEP) (CEZAR-VAZ et al., 2012).

The first phase of the research focused on being aware of the work environment. After securing the agreement of the rural company's managers and after having disclosed the purpose of the intervention, the nursing team responsible for the research - LAMSA members - observed the dairy farm workplace, in order to know the research scenario and the work performed by the women. This first exploratory phase included a systematic observation (GREEN \& THOROGOOD, 2004) of the workplace as well as the chance to talk to the employees. The registration of the workplace observation was performed using a field diary written by the nursing team and included audio and video recording of the visit.

\section{Subjects}

The study subjects were women working on a dairy farm of a rural company from the city of Rio Grande, Rio Grande do Sul, Brazil. The company where the Project was developed had 260 employees. However, the Project was not offered to all employees but only to 20 women working on the dairy farm. This was a demand from the company so that the intervention process only had women from this department of the company, due to frequent resigns of the women working in the sector because of the job characteristics. Although these women represent a minority of all workers, they have high social and economic importance. The farm is classified in the 10th place in Brazilian rankings of milk production. This fact undoubtedly contributes to Brazil's position as the 5th largest milk producer in the world.

\section{Questionnaire and data collection}

The data collection was carried out between July and October 2011, through a structured interview with a questionnaire which included participant characteristics; workplace characteristics; activities performed in the dairy farm work, which included milking and animal care (hygiene, medication application and feeding of calves), workplace hygiene and work coordination/organization (leadership at work, milk quality and quantity measurement); dermatological clinical alterations related to dairy farm work, usage of individual protection equipment and dermatological physical exams. After the first period of the research, the authors organized the next phases of the intervention process with the group studied.

In the second phase, Health Production Workshops (HPW) was held, consisting of verbal health care actions, previously scheduled with the company managers. In the first HPWs, the research purpose and methodology was presented, the themes to be worked on and the scheduling of days and times. It is important to highlight that there have been other interventions concerning the health of the women besides the one presented in this scientific production, which focused on stimulus to self-esteem, chronic disease prevention, musculoskeletal diseases and breast and uterine cancer prevention. These will be worked on in other studies during the research. A total of nine HPW were held, all lasting 90 minutes each, in a period of six weeks. All took place near the participants' workplace, in a room made available by the managers. The HPWs averaged nine participants.

The intervention process on dermatological health took place in two HPWs. Contents such as skin layers, their function, and individual protection equipment and possible dermatological changes related to dairy farms were discussed. In this phase the registration of systematic observation in field diaries and audio and video recording took place. The nursing team conducted the data transcription.

The third phase consisted of the evaluation of the actions proposed in this intervention. The intervention evaluation always took place in the meeting following the previous one, which concerned what was being evaluated and it consisted of open 
questions. The questions approached behavioral changes of working women after the intervention. During this third phase the systematic observation registered in the field diaries and the audio and video recording took place. The nursing team transcribed both. The evaluation of the meetings concerning dermatological health included questions of skin functions and care.

Data analysis

The database and the monitoring data were extracted from the project databank. The data referring to the clinical alterations were inserted into a databank in the software Statistical Package for the Social Sciences (SPSS), version 19.0, for descriptive analysis. In terms of qualitative data, the interest outcomes were indicators of change in the behavior of the participants concerning dermatological health. All discussions, which happened during the meetings, were registered in field diaries, recorded and transcribed for review. Theme analysis was developed from the emerging themes ranked by similarities (GREEN \& THOROGOOD, 2004).

\section{RESULTS}

\section{Participant characteristics}

The results of the present study have a sample of 20 women working at a rural company in Rio Grande, Rio Grande do Sul, Brazil. Most women, 16 (80\%), were white; 14 (70\%) were married or living with their partner; age ranged between 21 and 48, averaging $31.4 \mathrm{~s}( \pm 6.45)$ and eight (40\%) had incomplete elementary school studies. Their working time ranged between three months to six years, averaging 2.53 years $( \pm 1.82)$ and most, 10 (50\%) indicated that they were earning more than $\mathrm{R} \$$ $1.200,00$.

\section{Workplace characteristics}

Results of the questionnaire application on the workplace characteristics demonstrated that 19 (95\%) of the women indicated the presence of dust and humidity. For 12 (60\%) of them the room temperature at the workplace was not pleasant, 10 (50\%) indicating that was very cold and five (25\%) very hot. Concerning illumination at the workplace, $14(70 \%)$ of the women mentioned that it was adequate. Such data indicate that there are factors at the workplace in dairy farms which interfere in maintaining the health of the women, a reality confirmed by 15 (75\%) of them. Thus, the workplace presented risks for human health for 18 (90\%) of the women working there. Self referred health risks by women working on the dairy farm include for 8 (40\%) exposure to damp environment; 6 (30\%) dealing with the cows (kicks); 3 (15\%) contact with cow dander; 2 (10\%) exposure to weather factors (rain, sun, cold) and $1(5 \%)$ contact with cow excrement.

For dermatological protection at the workplace, the women working on the dairy farm referred to use of individual protective devices (IPDs) made available by the company. All women reported wearing latex gloves; 19 (95\%) apron; 18 (90\%) jackets; 12 (60\%) plastic sleeves; 08 (40\%) cap; 04 (20\%) boots; 03 (15\%) safety goggles; 03 (15\%) masks; 02 (10\%) uniform and; 01 (05\%) hat.

Dermatological clinical changes related to work on the dairy farm

The occurrence of dermatological changes in the dairy farm work was mentioned by 12 (60\%) women. The activities performed by these women included for 11 (55\%) milking, taking care of the animals and workplace hygiene; for three (15\%) taking care of the animals and workplace hygiene; for two (10\%) milking and workplace hygiene; for two (10\%) milking, caring the animals, workplace hygiene and work coordination/organization; for one (5\%) taking care of the animals and work coordination/organization and for one (5\%) milking.

In terms of the description of dermatological changes referred by the women in the dairy farm activity, nine (45\%) mentioned allergies on their hands, in which two (10\%) stated that it was due to contact with the dust found inside the latex gloves and two (10\%) due to the excessive contact with water during work. The other participants, who referred the same type of skin allergy due to work, did not mention the reason. Three (15\%) women mentioned itching on the hands, in which one $(5 \%)$ associated the change with the use of the gloves due to the contact with the talcum powder found inside them and the other two women (10\%), did not indicate a reason, only referring the presence of erythema for one and phlyctena for the other.

Another dermatological change related to the use of latex gloves was manifested by one woman (5\%), who mentioned having a sensation that her hands were raw, as if burned, due to the contact with the talcum powder found inside the gloves. There was also a woman (5\%) who referred to having small wounds on the skin, two (10\%) mentioned mycose on the hands and one (5\%) reported small blisters on the hands, all associated with work but without a direct indication for the reason. One (5\%) woman referred 
to have some spots on the skin, associating their appearance with sun exposure during the work on the dairy farm. Eight (40\%) women stated that they did not experience dermatological changes.

During the HPWs the dermatological changes mentioned by the women working on the dairy farm concerning the use of IPD during work was listed. The relations made by the women were: (a) the use of latex gloves with the identification of allergies due to the contact with the talcum powder found in the gloves, (b) the use of leather boots with the presence of humidity in the feet, (c) the use of large clothes with the identification of dermatitis in lower members due to the attrition between the members. The solution the women found to solve the attrition problem was to wear tighter clothes under the large clothes worn for working. Items (a) and (b) did not present control indication by the participant women; however, specific care concerning these problems was considered during the HPWs.

One of the procedures used to stimulate the sensibility of the working women and their self esteem concerning dermatological care was to take them for a group walk. The walk was conducted by two nurses in the surrounding areas of the HPWs. During the walk, the participants were guided and motivated to wear sunscreen, hats, comfortable shoes and clothes, in order to connect dermatological care with clinical health. The place where the walk took place was surrounded by trees, calm, free of noise and intense sounds, so characteristic in the urban environment. Such an initiative aimed to gather the group together and warn them about the importance of taking good care of the largest human organ, taking advantage of a place which would provide serenity for the activity.

The magic box technique was also used, which consists of the preparation of a closed box which contains painted objects painted with washable paint. A participant was asked to guess which objects were inside the box. However, the participant did not know that the objects were painted with gouache and that when they removed the hand from the box, it would be dirty. This technique was used to make a connection of contaminants quite often imperceptible to the eye but pathogenic to human beings.

After the use of the magic box technique, the importance of washing the hands was highlighted, based on the demonstration of the technique to the participants. This action was conducted with the help of a poster showing the nine steps of hand washing. Later, the women were asked to perform the technique with the help of the nurses. Afterwards, the poster was placed where there was more circulation of women in the workplace (restrooms, dressing rooms and cafeteria). Each participant was also given a package of moisturizing cream for the hands. Use of the cream was motivated during and after every work shift, after the appropriate hand washing and drying. For each technique performed during the second phase of the intervention on dermatological disorders, the nursing team motivated feedback on the issues discussed and their importance for dermatological health.

Intervention process evaluation

After the two phases were performed, the research was concluded with the evaluation of the women working on the dairy farm after the HPWs on dermatological clinical health. Explanation concerning dermatological function after intervention includes skin hydration (oiliness) (03 explanations), body temperature stabilization (sweat) (03), body protection (coating) (02), sensitivity (touch) (01), and body movement (elasticity) (01). The explanation concerning the change of behavior after the intervention include moisturising the hands (05 explanations), using warm water during skin hygiene (03), maintaining body hygiene (02), drying the body well (between the fingers) (02), being careful about the use and exposure to chemicals (01), and washing the hands (01).

\section{DISCUSSION}

The organic changes and the consequent injuries of people working in the rural environment represent an important social and financial issue and a serious health problem for the population living and working in such an environment (MATHER \& LOWER, 2001). Therefore, considering the important function that the women working in these surroundings have in the economic development of the region in which they live, they need some support in terms of health. Among the morbidities to which rural workers are exposed, dermatological diseases should be highlighted, representing $56 \%$ of the total diseases. Other diseases include respiratory, musculoskeletal and hearing loss (RAUTIAINEN \& REYNOLDS, 2002). This reality is also highlighted in the present research as $60 \%$ of the participant women mentioned presenting dermatological changes, with prevalence for allergies in $45 \%$ and which were indicated as health risks due to the workplace and environment.

The rural constructions need adequate ventilation and illumination for the work activities they are built for, with a constant process of cleaning 
and disinfection so that the harmful action of pathogenic agents is avoided. However, most of the rural companies, such as dairy ones, have a limited budget and, at times, insufficiency in offering the necessary support for the workplace (SELL et al., 2005).

The appearance of skin allergies with the work performed on a daily basis at dairy companies may be related to the use of latex gloves, due to the talcum powder found inside the gloves and the moisture on the hands by the constant use of them. Similarly, in Denmark, data point out that about one third of people working in dairy companies have two or more symptoms related to dermatological changes. The relation is in the abusive use of disinfectant in hand hygiene and in the intensification of hand moisture. The adoption of protection measures such as cotton gloves and the use of procedure gloves is recommended as well as the use of skin moisturizer. Although the symptoms manifested on the skin, triggered at the workplace do not represent a serious problem to the health of workers, the harmed skin exposes the worker to susceptibility to develop possible symptoms and/or illnesses. This is exemplified by the fact that $88 \%$ of all workers at cheese factories did not report the presence of eczemas when they were admitted to work, although they have developed such problems during their daily activities at the workplace (SELL et al., 2005).

The contact dermatitis itching type is the most common of all skin alterations and it may be related to the use of soap when the hands are washed. The severity of this reaction is proportionally related to the concentration and the exposure time to the harmful agent (NIJHAWEN et al., 2009). It can be recalled that the skin discontinuity may facilitate the penetration of allergens in the skin. In the dairy cattle business in Finland the high rates of occupational dermatosis may be related to the exposition to cow dander, mainly in the autumn and winter seasons. This happens due to the fact that the cows are kept in closed environments during this time (KANERVA \& SUSTAIVAL, 1996).

In Brazil, a study performed in São Paulo on the frequency of dermatitis due to occupational contact highlighted that among the 630 patients studied, 10,9\% present occupational contact dermatitis and all of them, 91,5\% were related to work at humid places. Concerning the location of the dermatitis, $70 \%$ were found in the hands, followed by arms with $30 \%$, legs $12 \%$, feet $7 \%$ and cephalic segment $6 \%$, in which the metals and rubber components were the main sensitizing ones (DUARTE et al., 2010).
Allergic dermatitis due to contact with rubber is caused by the hypersensitivity mechanism. On a lower scale, there is concomitantly the reaction to latex or contact urticaria, commonly linked to the use of gloves. The content of latex gloves therefore may cause different types of reaction to the employee using them, such as contact dermatitis caused by irritation, allergic dermatitis of contact due to the chemicals and contact urticaria (FERNANDEZ et al., 2009). Thus, despite latex gloves are an individual protective device at the workplace, they may cause changes in the dermatological integrity (OLIVEIRA \& ALCHORNE, 2011), and, therefore deserve attention from the workers, managers and health professionals. Another form of dermatological exposure of dairy factory workers in the rural environment is associated to the contact with cow excrement, mainly characterized by manual tasks involving the hands and the forearms (JEPSEN \& FLYVHOLM, 2007).

The dermatological exposure during the work process on the dairy farm is also related to the risks of daily contact with the cows, when the workers are also exposed to animal kicks (MAIA \& RODRIGUES, 2012). This reality is found in a study developed at a milk factory in Finland, in which the injuries related to the handling of the animals represent 43\%, being predominant in working women (77\%). Among these, $80 \%$ had suffered one or more injuries in two years, characterizing the work as dangerous due to the unexpected behavior of the animals (KALLOINIEMI et al., 2011). This fact was also highlighted in São Paulo with people working in the dairy cattle industry (SILVA et al., 2012).

The use of new production methods in the rural environment may, therefore, bring advantages by reducing harmful factors to the health of rural workers. One of the suggestions presented is the reduction of manual work and the setting of high standards of hygiene in the dairy work. However, despite presenting a relation to dermatological disorders, the existing risks in the adoption of such measures should be taken into consideration as well as the providence of health assistance (SELL et al., 2005). Therefore, health educational intervention, with emphasis on the prevention of specific complications in the rural environment and in health maintenance is significant (MATHER \& LOWER, 2001; PANDEY et al., 2007), as the lack of basic knowledge about the health of women is a limitation to be overcome by health professionals (MATTHEWS et al, 2006). The dermatological clinical health of women working on dairy farms is harmed because the women work on a daily basis in environments in which their hands are constantly damp. One way of minimizing the damage 
that dampness may cause to dermatological health is the use of moisturizing creams for the hands (SELL et al., 2005). This is a recommended practice in the present research, with moisturizing creams being made available for all the participants.

The quality of information and assistance is technical and the health of the rural worker is essential to overcome organic and functional changes related to the perception of risks at work (CHAPMAN et al., 2009). Therefore, enabling investigations, which interfere in rural health, mainly through nurses, contributes towards preventive actions, which strengthen health production, bringing the workers in this area closer to care through an educational dissemination of knowledge towards occupational health.

\section{CONCLUSION}

The practice of this Nursing intervention, although with a small group of participants, used an intentional sampling, justified by the interest in studying a group working on a dairy farm in a rural environment and with the work carried out exclusively by women. Therefore, it is believed that the analysis can be spread to other countries in order to avoid the clinical consequences resulting from such work because it has been shown that the work performed in the rural environment plays a meaningful role in terms of income for the families and not only those activities traditionally done at home and usually considered as tasks exclusively for women.

\section{REFERENCES}

BRASIL. Norma reguladora de segurança e saúde no trabalho na agricultura, pecuária, silvicultura, exploração florestal e aquicultura. Brasília, DF, Brasil, 2005.

CARRUTH, A.K. et al. Nonfatal injury experiences among women on family farms. Clin Nurs Res, v.11, p.130-148, 2002.

CEZAR-VAZ, M.R. Health, risks and occupational diseases: an integrated study in different work environments. Rio Grande (RS): Universidade Federal do Rio Grande, 2010. 58p.

CEZAR-VAZ, M.R. et al. Risk perception and occupational accidents: a study of gas station workers in southern Brazil. Int J Environ Res Public Health, v.9, p.2362-2377, 2012. Available from: <http:/www.mdpi.com/1660-4601/9/7/2362>. Accessed: Sept. 10, 2012. doi: 10.3390/ijerph9072362.

CHAPMAN, L.J. et al. Intervention to increase adoption of safer dairy farming production practices. Public Health Rep, v.124, p.125-133, 2009. Available from: <http:/www.ncbi.nlm.nih.gov/pmc/articles/ PMC2708663/pdf/phr124s10125.pdf>. Accessed: Sept. 14, 2012.

DUARTE, I. et al. Frequência da dermatite de contato ocupacional em ambulatório de alergia dermatológica. An Bras Dermatol, v.85, p.455-459, 2010.
FENTON, G.D. et al. Occupational health behaviors and habits of women on dairy farms in Pennsylvania. J Agromedicine, v.15, p.16-23, 2010. Available from: <http://www.tandfonline.com/doi/ pdf/10.1080/10599240903389664>. Accessed: Sept. 10, 2012. doi: 10.1080/10599240903389664.

FERNANDEZ, O. et al. Associação de urticária de contato e dermatite alérgica de contato com borracha. An Bras Dermatol, v.84, p.177179, 2009.

GREEN, J.; THOROGOOD, N. Qualitative methods for health research. London: Sage, 2004. 320p.

JEPSEN, K.F.; FLYVHOLM, M.-A. Identification of subjects with atopic dermatitis in questionnaire studies. Contact Derm, v.56, p.218-223, 2007.

KALLOINIEMI, M.K. et al. Safety and animal handling practices among women dairy operators. J Agric Saf Health, v.17, p.63-78, 2011. Available from: < https://elibrary.asabe.org/abstract.asp?aid= 36233\&t=2\&redir=\&redirType>. Accessed: Sept. 27, 2012.

KANERVA, L.; SUSTAIVAL, P. Cow dander: the most common cause of occupational contact urticaria in Finland. Contact Derm, v.35, p.309-310, 1996. Available from: <http://onlinelibrary.wiley. com/doi/10.1111/j.1600-0536.1996.tb02400.x/pdf>. Accessed: Sept. 25, 2012. doi: 10.1111/j.1600-536.1996.tb02400.x.

LUCA, L. et al. Unleashing the potential for rural development through decent work: building on the rural work legacy: 1970s-2011. Geneva: International Labour Organization. Geneva, 2012. 209p.

MAIA, L.R.; RODRIGUES, L.B. Saúde e segurança no ambiente rural: uma análise das condições de trabalho em um setor de ordenha. Ciênc Rural, v.42, n.6, p.1134-1139, 2012. Available from: <http:// www.scielo.br/pdf/cr/v42n6/a15712cr5475.pdf>. Accessed: Sept. 16, 2013.

MATHER, C.; LOWER, T. Farm injury in Tasmânia. Aust J Rural Health, v.9, p.209-215, 2001. Available from: <http:// onlinelibrary.wiley.com/doi/10.1046/j.1440-1584.2001.00414.x/ pdf $>$. Accessed: Sept. 10, 2012.

MATTHEWS, H.L. et al. Rural women and osteoporosis: awareness and educational needs. J Rural Health, v.22, p.279283, 2006.

NIJHAWEN, R.I. et al. Contact dermatitis: from basics to allergodromes. Pediatr Ann, v.38, p.99-108, 2009.

OLIVEIRA, H.R.; ALCHORNE, A.O.A. Fundamentos sobre o conhecimento dos aditivos químicos presentes nas luvas de borracha. An Bras Dermatol, v.86, p.911-916, 2011.

PANDEY, P. et al. Informing resource-poor populations and the delivery of entitled health and social services in rural India. J Amer Med Assoc, v.298, p.1867-1875, 2007.

RAUTIAINEN, R.H.; REYNOLDS, S.J. Mortality and morbidity in agriculture in the United States. J Agric Saf Health, v.8, p.259276, 2002.

SELL, L. et al. Implementation of an occupational skin disease prevention programme in Danish cheese dairies. Contact Derm, v.53, p.155-161, 2005.

SILVA, T.P.P. et al. Serão os carrapaticidas agrotóxicos? Implicações na saúde e na percepção de riscos de trabalhadores da pecuária leiteira. Ciênc saúde coletiva, v.17, p.311-325, 2012. 